\title{
Prospects of Asian Infrastructure Investment Bank
}

\author{
Makmun Syadullah \\ Fiscal Policy Agency, Ministry of Finance, Republic of Indonesia \\ makmunsyadullah@yahoo.com
}

\begin{abstract}
Infrastructure investment is one of the new sources of growth beside trade. However, the availability of infrastructure has become one of the major problems in the process of economic development in the region. Given the need for huge capital infrastructure in the region and the presence of the financing gap in infrastructure financing, the People Republic of Chinese (PRC) initiated the establishment of the Asian Infrastructure Investment Bank (AIIB). Thus, AIIB is expected to accelerate economic development and integration of Asia through the promotion of investment in the infrastructure sector. AIIB have several priority areas include transport, energy, communication, industry, and agriculture. The study used qualitative methods to compare the performance of various Multi Development Banks (MDBs) that existed such as IMF, ADB, IDB and WB with AIIB work plan. The results of this study will be expected to produce policy recommendations related to the formation of AIIB. AIIB initiative is the establishment of a relevant step with the spirit of accelerating economic development and integration of Asia to promote investment in the infrastructure sector. AIIB priority areas including transportation, energy, communication, industry, and agriculture is also a priority in developing countries. Openness in terms of membership (open regionalism) also showed that AIIB not only managed exclusively by the emerging countries in Asia but also opened to countries outside the region. The prospects of AIIB will be determined by how far the founding of PRC government transparency in every process both on stage and in the establishment of operational AIIB, how funding of AIIB direction forward and ensure it will not happen tied financing. This condition will be considered countries in the Asian region to join as founding members of AIIB.
\end{abstract}

Keyword: Infrastructure, multi development banks, investment

\section{Introduction}

Infrastructure investment is one of the new sources of growth outside the trade. However, the availability of infrastructure has become one of the major problems in the process of economic development in the countries of the region. Issues of development and infrastructure investment have begun to be discussed at the APEC Summit Vladisvostok before 2012 Russia. APEC leaders realized that the development of regional infrastructure is a very important investment related to economic development and regional connectivity. Infrastructure investment is needed in Asia Pacific over the period 2010-2020 that is estimated at US\$ 8 trillion. According to the World Bank, the infrastructure needs of developing countries is estimated to reach US\$1 - 1.5 trillion every year. Meanwhile, according to the OECD, the funding needs for infrastructure includes telecom, highways, railways and electricity up to 2030 is expected to reach 2.5 percent of world GDP, or approximately US\$ 118 billion. OECD (2010) also estimated the funding needs for energy infrastructure (such as gas, oil and coal) reached USD 71 trillion. Up to now, various governments have yet to find a source of funding to meet the needs of an increasingly infrastructure complexity. On the one hand, the infrastructure funding sources still rely on traditional finance, i.e the government budget. The use of the government budget is expected to be increasingly difficult to rely on the front, because the growing of public demands for social spending such as, security, and others. While the sources of the government's budget as tax receipts taxes both central and local taxes increasingly difficult to increase taxpayers paying higher taxes.

On the other hand, the international financial crisis that occurred in 1997 caused in the position of the infrastructure in a state of dilemma. Infrastructure spending in various governments has a tendency to decrease. It is encouraging to find effective ways and development models that help to mobilize regional and domestic savings to encourage sustainable economic growth and promote regional integration. In this context, infrastructure development has been given special priority by international community. Investment in infrastructure has a strong economic spillover effects. Every US\$ 1 investment in 
infrastructure can result in the need to invest US\$ 3 - \$ 4 in other economic sectors. In Asia, every \$ 1 billion investment in the infrastructure sector creates 18,000 employment opportunities. According to ADB estimates, investment demand for infrastructure development in Asian countries between 2010 and 2020 to touch USD 8 billion with an additional \$ 290 billion for regional projects. The need for huge capital infrastructure in the region and the presence of the financing gap in infrastructure financing, encourage the PRC initiated the establishment of the Asian Infrastructure Investment Bank (AIIB). Through, AIIB expected to accelerate economic development and integration of Asia through the promotion of investment in the infrastructure sector. AIIB has priority areas includes transport, energy, communication, industry, and agriculture.

As a follow up to the above initiatives, the $1^{\text {st }}$ Multilateral Meeting on Establishing the Asian Infrastructure Investment Bank has been organized. The purpose of this meeting is to conduct consultations between the parties approached by the Chinese government to become a founding member of AIIB including the 10 ASEAN countries, Pakistan, Sri Lanka, Mongolia and South Korea. AIIB on the one hand has potential for the occurrence of the struggle for influence and market share among financial institutions. Still the amount of funding needs for infrastructure in Asia countries will make competing infrastructure financing institutions. Currently a variety of financial institutions such as the Japan Bank for International Cooperation (JBIC), and the Asian Development Bank (ADB) is ready to finance infrastructure projects in the various countries in Asia. In order to improve the ability of providing loans to its member countries, AIIB need to obtain additional capital through the issuance of long-term debt (bonds/bond) or short-term (commercial paper). The ability in getting additional capital will be determined by AIIB rating, which indicates the level of risk AIIB. Therefore, the AIIB rating outlook needs to be analyzed. Finally, the AIIB prospects will be determined by the response of ASEAN member countries. This paper, therefore, will analyze the portrait of ASEAN member countries support for the proposed establishment of AIIB.

\section{Methodology}

The study used qualitative methods to compare the performance of various MDBs that has existed as IMF, ADB, IDB and WB with AIIB work plan. The results of this study will be expected to produce policy recommendations related to the formation of AIIB. The study was also supported with the focus group discussion with several relevant stakeholders who has concern toward this issue. In order to learn the best practice, the literature review was conducted like collecting information from relevant papers and report from MDBs and other relevant banking sectors both public and private.

\section{Literature Review}

Infrastructure Funding Scheme: Infrastructure is the most basic public infrastructure to support economic activity of a country. Availability of infrastructure determines the level of efficiency and effectiveness of economic activity. Given the vital infrastructure for economic development, it is the duty of government infrastructure development entirely. Empirical data shows that there is a strong relationship between the availability of basic infrastructure in the economy. The study by Aschauer (1989) concluded that the availability of infrastructure services is an important production factor. The study also found that the decline in productivity may be caused by the deterioration of the availability of infrastructure services. Meanwhile, Berndt and Hansson (1991) suggested that the increase in infrastructure services can reduce the cost of production. Morrison and Schwatz (1992) declare that the availability of infrastructure services proven to reduce the cost of production factors. Norton (1992) showed that the infrastructure in the telecommunications sector has a significant positive impact on economic growth. Briefly, the studies above show that investments in infrastructure have a positive impact on the economy.

Various studies to measure impact of infrastructure in the economy, among others, conducted by the World Bank (1994) which states that the economic growth of one percent turned out to be closely related to the growth in the availability of infrastructure services by one percent anyway. Further studies measuring the elasticity of the availability of infrastructure to the economy performed by Roller and Waverman (1996), Canning (1999), Marianne Fay (1999), Calderon and Serven (2002). Various studies show that it has a significant infrastructure investment and positive impact on the economy. The problem is the increase in demand is not matched by the ability of the Government to provide funding for 
infrastructure development, even from year to year decrease government's financial capability. To bridge the decreased ability of the government to fund infrastructure, then it needs to develop a range of funding schemes such as the Public-Private Partnership, business to business and SPV scheme.

International Financing Scheme: Issues on Infrastructure Crisis have strong linkages with the financial crisis and trade that hit the global economy. Infrastructure market liberalization is a key strategy in order to restore financial market. Same with the invasion in food markets, agriculture, climate market, social insurance market, all of which are encouraged to be a crutch for the stability of financial markets. Although infrastructure investment are also considered important in order to facilitate the flow of investment and trade in all sectors, but the most important goal is the infrastructure investment itself and how to create a broader financial markets for the private sector to absorb state money and public finance in a broader scale in order to enter the infrastructure market. There are at least three international financial institutions that can be a source of infrastructure funding, namely:

- Multilateral Development Banks, including the World Bank, the Asian Development Bank (ADB), and other financial institutions that become affiliates such as the Multilateral Investment Guarantee Association (MIGA). Under certain circumstances, these agencies can offer credit enhancements such as partial risk guarantees to the project company and the lenders.

- Foreign \& Domestic Commercial Banks providing debt financing for the project. It may be possible to secure all domestic debt financing for projects that are smaller, but larger projects may require merging with government financing.

- ASEAN Infrastructure Fund (AIF). AIF is an ASEAN infrastructure financing institution established to provide financial support for infrastructure development in ASEAN by utilizing the excess liquidity in the region.

The World Bank was established to promote long-term foreign investment loans on reasonable terms. The purposes of the Bank, as set forth in the 'Articles of Agreement' are as follows: (i) To assist in the reconstruction and development of territories of members by facilitating the investment of capital for productive purpose, (ii) to promote private investment by means of guarantee or participation in loans and other investments made by private investors, (iii) when private capital is not available on reasonable terms, to supplement private investment by providing on suitable conditions finance for productive purpose out of its own capital funds raised by it and its other resources, (iv) to promote the long-range balanced growth of international trade and the maintenance of equilibrium in balances of payments by encouraging international investment for the development of the productive resources of members, thereby assisting in raising productivity, the standard of living, and conditions of labor in their territories, (v) to arrange the loans made or guaranteed by it in relation to international loans through other channels so that the more useful and urgent projects, large and small alike, will be dealt with first, and (vi) to conduct its operations with due regard to the effect of international investment on business conditions in the territories of members and in the immediate postwar years, to assist in bringing about a smooth transition from a wartime to peacetime economy. The Asian Development Bank (ADEB) is being one of the Multilateral Development Banks, was founded in 1966 by 31 member governments to promote the social and economic progress of the Asian and Pacific region. Over the past 31 years, the Bank's membership has grown to 57, of which 41 are from within the region and 16 from outside the region.

The Bank's principal functions are (i) to extend loans and equity investments for the economic and social development of its developing member countries (DMCs); (ii) to provide technical assistance for the preparation and execution of development projects and programs, and for advisory services; (iii) to promote and facilitate investment of public and private capital for development purposes; and (iv) to respond to requests for assistance in coordinating development policies and plans of its DMCs. The ASEAN Infrastructure Fund (AIF) is a joint initiative of the Finance Ministers of ASEAN and the Asian Development Bank (ADB) in an effort to provide financial support for infrastructure development in the ASEAN region. This initiative is motivated significant difference in the level of infrastructure development in ASEAN countries (infrastructure development gap). In addition, the presence of excess domestic liquidity (domestic resources) must be absorbed and utilized for infrastructure development in ASEAN. AIF, the implementation will be realized in a special purpose vehicle (SPV) that will be administered by ADB. Through the SPV, the capital that has been formed will then be leveraged. At a later stage, if the SPV has had top billing infrastructure projects that they fund, this bill can then be securitized to increase liquidity so as to increase its lending capacity anyway. Thus, the SPV will be able to mobilize funds at a higher level. At the same time, the SPV is going to be able to build a good track record for AIF. 
Developments of Regional Cooperation for Infrastructure Financing: Declining financial capacity of the government led to the deterioration of the quality of infrastructure services and delays in the construction of new infrastructure. Infrastructure network conditions like this will ultimately increase the cost of the user very large, impede economic mobility, increasing the price of goods and complicate efforts to improve the welfare of society. Facing the above conditions, one of the steps taken by the government is encouraging the private sector and community participation in the development and management of infrastructure. But the government's effort faces some constraints, which are: First, foreign private investment still increased, whereas most projects rely on foreign borrowing partnerships. Second, the source of funds of the banking infrastructure is very limited due to a mismatch between the timing of the project and repayment period of the loan. In general, infrastructure projects take between 15-30 years to pay off the investment, while banks generally are not interested in funding long-term projects. This condition is faced by almost all countries, especially in finding financing amid the global crisis. Attempts to access other sources of funding to finance infrastructure needs will be more efficient and it will it will have added value if there is an intensive regional cooperation.

According to the United Nations-ESCAP (2006) there are three advantages of regional cooperation in the presence of: (i) the funds collected will be greater, (ii) certain projects that cross national boundaries requires cooperation and coordination between one or more states; (iii) failure to address the crossborder infrastructure bottlenecks that would impede the development and intensification of regional supply network may trigger trade and income growth in the region. Recognizing some of the advantages of regional cooperation for infrastructure financing above, countries in Africa in 2001 forming The Emerging Africa Infrastructure Fund (EAIF), a public-private partnership that provides long-term financing for the construction and development of private infrastructure in 47 countries of sub-Saharan Africa (except Mauritius). EAIF provides US\$ 10 million to US\$ 36.5 million for projects in various sectors including telecommunications, transportation, water and electricity. EAIF established to address the lack of long-term financing for infrastructure projects in sub-Saharan Africa. EAIF offer loans in USD and EUR to private companies. This loan is for green field projects or for upgrades or expansion. Sourced funds from donor countries and by EAIF lent to commercial requirements. This loan is intended to support projects that (i) promote economic growth and reduce poverty, (ii) a broad-based benefit population groups, (iii) address issues of equity, and (iv) participate in the promotion of social rights, economy and culture.

The Middle East region has also established The Middle East and North Africa (MENA) Infrastructure Fund. MENA which established in the Dubai International Finance Centre (DIFC) is regional investors, with targeted investment in infrastructure and energy sectors across the Middle East and North Africa. Funding MENA sponsored by three leading investor in the Middle East and North Africa, namely Fajr Capital, HSBC Bank Middle East and Waha Capital. A dedicated investment team utilizing the support of the sponsors who are experienced to provide investment opportunities to investors, along with the capital and financial expertise to companies in which he invests. MENA has become one of the largest infrastructure funds and the most successful in the Middle East and North Africa.

\section{Analysis}

Important Elements of AIIB: AIIB will apply the principle of open regionalism and complementary role of the multilateral development banks that exist today. To that end, in the early stages, AIIB membership is expected to come from ASEAN member countries who are interested in joining. AIIB also opens up opportunities for countries in South Asia to join for example Pakistan, Sri Lanka, India, and others. The PRC has held the $1^{\text {st }}$ Consultation Meeting held in Beijing, on January 24, 2014. The meeting was attended by 15 countries (China, 10 ASEAN countries, South Korea, Sri Lanka, Pakistan, and Mongolia). The purpose of this meeting is to conduct consultations between the parties approached by the PRC to be become founding members of AIIB. This meeting discussed the issues paper prepared by the PRC which includes important elements of AIIB namely: mandate and operations, membership, governance, capital, and location.

Mandate and operations: AIIB is expected to have a mandate to accelerate the development and economic integration in Asia and encourage the development of productive infrastructure and construction related areas. In its operational AIIB will offer long-term loans, makes equity investments or provide warranties whole or in part related to the development of infrastructure that can encourage 
economic development in the member countries and help deepen connectivity and regional integration. Therefore, AIIB will offer long-term loans (similar to the ADB OCR loan and the World Bank IBRD loan) at affordable rates. AIIB can also provide guarantees for loans in infrastructure or make direct equity investments in the infrastructure sector. In order to meet the funding needs for very large infrastructure funds in Asia, AIIB will also explore ways to provide matching funds to the Multilateral Development Banks (MDBs) that exist and mobilize private funds. If conditions permit, AIIB might prepare a trust fund (trust funds) or other financial facilities to offer grants or soft loans to support infrastructure development in the region.

Membership: AIIB will apply the principle of open regionalism and complementary role of multilateral development banks that exist today. To that end, in the early stages, AIIB membership is expected to come from ASEAN member countries are interested in joining. Going forward, for the sake of development AIIB will be expanded to which countries outside the region, including non-sovereign institutions. On this subject appeared in a number of questions such as the difference in status between the founding members and non-founding members, will be the same whether AIIB members with ADB and why the consultation meeting is limited to 14 invited countries. The PRC as initiators of AIIB considers that the member states have the same rights, only founding members have the opportunity to draw up rules and sending its officials to sit in the organization AIIB, while the state is invited to focus more on restricted consultations, involving new afterwards wider.

Governance: Discussion on the issue of governance includes three aspects, namely the governance structure, the allocation of voice and decision-making rules. Associated with this governance, the PRC side said that the countries which become founding members have a great opportunity to define various rules in the decision-making process. Referring to the existing practice of MDBs, AIIB has a variety options for allocation of voting rights option. First, economic is allocating in proportion to shareholdings. In general, the practice adopted by most of the MDBs, this approach helps in adjustment of the rights of members to contribute and their economic responsibilities. Although it helps to mobilize the voting rights, but can pose the question on how the protection of minority shareholders in AIIB. To avoid a significant gap in sound between members, additional steps may be needed to balance the shareholder vote in a manner acceptable to all members.

Second, mixed approach including basic votes: This approach was adopted by IBRD and ADB. In this approach the voting rights based on the contribution of member states to AIIB. This is based on a sound basis of assignment to member states. To some extent, it shows the equivalence of the members and help to encourage participation in the management of medium and small shareholders to form a more balanced governance structure. However, the basic sound is usually limited to guarantee the rights of small shareholders. In IBRD, voice assessment is calculated as equity of 5.55 percent of the aggregate amount power of the voice of all members. While at the ADB, the basic sound is maintain ed at 20 percent of the total vote. The key question is how to set reasonable limits for the assessment base to strike the right balance between equality and efficiency.

Third, economic votes plus member votes: This method was introduced by the European Investment Bank (EIB), a regional development bank that could set an example for AIIB. In the EIB, the economic assessment is allocated based on the economic contribution of members. Meanwhile, each member state has one vote member. The decision was made based on a combination of economic valuation and appraisal of members, and thus helps to ensure equality of all member states, large or small.

Capital: Given the funding needs are very large for infrastructure development in the member countries and the number of infrastructure projects, the volume of annual lending AIIB projected to be US $\$ 5$ billion in the early years and will gradually be expanded to US\$10 billion, then the required initial capital greater. Because AIIB will not be able to mobilize resources from international capital markets at an early stage, the capital will depend on the contributions of its member countries. At the same time, the financing capacity of the founder members also needs to be taken into account in determining the location of the host country. Taking into account the funding needs and the capacity of the founder members, it is proposed that the initial authorized capital of AIIB determined at US\$ 50 billion with an initial deposit of 20 percent and will be increased in line with the development of banking operations. AIIB will also be open to all the countries of Asia and the countries of the non-regional in the future. As a regional bank in Asia, it is proposed that the ownership of shares of non-regional members in AIIB should 
not exceed 30 percent. The amount of paid-in capital by 14 founding members will be strongly influenced by the initial capital of AIIB.

AIIB will also design the capital structure (the ratio of callable and paid-in capital) to ensure that the capital requirements sufficient to meet working capital requirements and demonstrate a strong commitment founding member states to financing bank especially in the early stages. AIIB will gradually increase the capital by accessing the international capital markets in the future. The paid in capital also plays an important role in determining the adequacy of the capital and credit rating agencies. A review of the capital structure to other MDBs suggests that this ratio ranges from 20 percent to 50 percent at the beginning and the ratio gradually decreased over a period of time as these institutions have established themselves and expanded operations. Taking into account of the need to get a high rating and better utilize capital contribution by founding member, proposed that the ratio of paid-in capital can AIIB initially set at 20. This ratio can be set to make revisions after AIIB formed. Determination of the amount of contributions AIIB member states can also refer to other MDBs, the volume of GDP or using quota share in the IMF as a reference. As the largest country among the founding members, the PRC is willing to contribute as much as 50 percent of the capital. The currency used is US\$ or local currency agreed upon conditions. AIIB will offer loans with criteria that were similar to "hard loan" offered by MDBs that exist today.

Location: Through mutual agreement, the host country AIIB will be located in one of the founding members to support the mandate and operations AIIB and will open representative offices in the member states if needed. In this regard, the host country should have the basic economic and social development is strong in the long term, has the financial infrastructure that can support the operational of AIIB, has lines of communication and transportation is convenient and has adequate international facilities and attract international professionals. Related to this, the three countries have volunteered to be the host country, the PRC (Beijing), South Korea (Seoul), and Malaysia (Kuala Lumpur).

Operations, Governance Structure, Share of Capital Stock and Voting: On March 28, 2014, held in Beijing, PRC conducted Working Group for Establishment of AIIB. In the working group discussed four issues related to AIIB, i.e. operations, governance structure, and share of capital stock and voting. First, with regard to operations, based on the results of the working group estimated of AIIB loan at this early stage would reach 90 percent of the value of assets. Furthermore AIIB will begin to issue bonds after a full standing as a legal entity. At the end of the third year is expected accumulation ratio of outstanding debt (balance of debt) of the paid-up capital will reach five times and stabilized at that level for the next period. According to Anat and Martin (2014), minimum leverage ratio for financial institutions (banks) with assets of $\$ 50$ billion is 8 percent, while the assets of more than USD 50 billion should leverage ratio is 15 percent. This is in line with Bassel III which requires debt to equity limit of 15 percent for financial institutions with assets of more than USD 500 billion. In the early stages of establishment AIIB, disbursement plan 90 percent of the assets may be too ambitious and very risky, especially if the global financial crisis. Besides it would AIIB, dependent on the ability of its personnel in analyzing credit risk.

Unlike the World Bank and Asian Development Bank loans are a higher priority for poverty reduction and social development, business character of AIIB intended for infrastructure development in Asia. Besides, it is also intended to develop regional connectivity and economic cooperation, to overcome infrastructure deficiencies and impact of infrastructure construction to accelerate the economic development of member countries and regions. AIIB built the basic principles and perceptions for future business models. The projection of the paid up capital and loan-scale projection at an early stage AIIB made in two scenarios, but the Chinese prefer the first scenario. The second scenario is as follows:

Table 1: Possible Lending Scale (USD billion)

\begin{tabular}{llllll}
\hline Base Line 1 & Year 1 & Year 2 & Year 3 & Year 4 & Year 5 \\
\hline Accumulated paid-In capital & 3 & 5 & 7 & 8,5 & 10 \\
$\begin{array}{l}\text { Project Lending Scale } \\
\text { Base Line 2 }\end{array}$ & 6,2 & 20,4 & 38,7 & 47,2 & 56,9 \\
$\begin{array}{l}\text { Accumulated paid-In capital } \\
\text { Project Lending Scale }\end{array}$ & 2 & 4 & 6 & 8 & 10 \\
\hline Soln & 4 & 16,3 & 33,3 & 44,3 & 56,5 \\
\hline
\end{tabular}

Source: Working Group for Establishment of AIIB 
AIIB loan will be focused on the field of transport infrastructure, energy, urban development, telecommunications/logistics and agriculture. Meanwhile lending to member countries are expected not related to the share capital, however, refer to some criteria such as the requirement of protection (safeguards requirements), the impact on development, financial feasibility (financial viability), and so forth. Absorption capacity of the country and the exposure of a country should also take into account the financial support provided. In the context of safeguards, projects that will be funded by AIIB should be selected based on type, location, scale, and potential environmental impacts both direct and indirect impacts. ADB For example, since July 2009, the Board of Directors approved the Safeguard Policy Statement, which projects funded by the ADB should consider environmental issues. AIIB can design projects that will be funded by making a variety of categories, for example: the first category is projects that can lead to worse environmental impact, with regard to sensitivity and diversity impact. For projects in this category must be equipped with an Environmental Impact Assessment document (EIA), including environmental management plan (EMP environmental-management plan). The second category of projects with small size and volume, resulting in environmental impacts but recovery efforts are very likely to do. For instance are projects like initial environmental examination (IEE-initial environmental examination). The third category is projects that have no impact on the environment.

AIIB organizational structure will be made efficient and effective. For that AIIB will be set up by sector, optimizing the credit process and improving operational efficiency and minimizing the hidden costs to the borrower. AIIB will focus on targeted projects and the most needed and the project components. Maturity structure of loans should be designed to meet the needs of members, providing technical assistance for institutional capacity building, project design and management, as well as setting up a trust fund to offer grants or soft loans to low-income countries to provide technical assistance for institutional capacity building, project design and management. In addition, AIIB will also collaborate with various MDBs financing available and to mobilize private funds for financing the project. AIIB will encourage the development of regional capital markets for financing, using various forms of credit enhancement scheme to raise the AIIB credit rating, maintain a leverage ratio at a reasonable level and ensure risk control.

Secondly, in regard to the management structure of AIIB, there are three levels namely (i) the board of governors, (ii) the board of directors, and (iii) president (management). The composition of the board of governors of each state governor and deputy governor commissioned. Deputy Governor is independent of the voting rights. His power recognize new members, changing the size of capital, net income decide, approve changes to the base document, issued membership, choose the director and the president, approving the annual report. While the board of directors elected by the board of governors and is composed of 12 non-resident members and meets four times a year. Board of directors will decide on budget and submit a report on the direction of the board of governors. Quorum of the board of governors and the board of directors at a meeting, two- thirds of the voting power and half of the total number of governors or directors. The president is the chairman of the board directors and performs daily activities including the authority to appoint or dismiss staff or employees of the Bank; the President is a member of a recognized professionalism, experience and ethical integrity. The President may appoint a vicepresident. Third, in the context of the share of capital stock. For regional members are expected to contribute 70-75 per cent of the capital stock, while the non-regional members to contribute 25-30 per cent. The amount of this capital allocation will be based on a formula that is calculated based on the amount of the gross domestic product (GDP), GDP per capita, the amount of exports and government revenues from taxation. Fourth, is voting. Voting will be based on the basic power voters and voters share. Basic voters only for developing regional founding members are calculated based on a percentage that is calculated based on the formula agreed by consensus. While the share of voters are allocated based on the share of capital stock, voting power is designed in referring to the IBRD and ADB in order to protect the smaller members.

Learning from Existing MDBs Performance: Although the status of the international financial institutions, not all MDBs are able to run their businesses effectively. This is evident from the outstanding loan to equity ratio. IMF and World Bank were able to play their capital respectively 5.4 times and 3.6 times, while the IDB is able to rotate 1.1 times their capital. On the other hand, the ADB is only able to rotate 0.4 times of their capital. 
Table 2: Performance MDBs

\begin{tabular}{|c|c|c|c|c|c|c|}
\hline \multirow[t]{2}{*}{ MDBs } & \multirow[t]{2}{*}{ Equity } & \multicolumn{2}{|c|}{ Placement of Assets } & \multirow{2}{*}{$\begin{array}{l}\text { Loan to } \\
\text { Equity Ratio }\end{array}$} & \multirow[t]{2}{*}{ Currency } & \multirow{2}{*}{ Year } \\
\hline & & $\begin{array}{l}\text { Loan } \\
\text { (Outstanding) }\end{array}$ & $\begin{array}{l}\text { Other } \\
\text { Instrument }\end{array}$ & & & \\
\hline IDB & $6,953.55$ & $7,783.85$ & $3,075.47$ & 1.12 & ID (million) & 2012 \\
\hline IMF & $16,565.00$ & $90,182.00$ & $19,168.00$ & 5.44 & USD (million) & 2013 \\
\hline WB & $37,636.00$ & $136,325.00$ & $62,916.00$ & 3.62 & USD (million) & 2012 \\
\hline ADB & $163,129.00$ & $64,279.00$ & 131.00 & 0.39 & USD (million) & 2012 \\
\hline
\end{tabular}

Source : financial statements of IDB, IMF, WB and, prepared

The low ability of ADB lending is a result of the low absorption of the approved credit. Based on ADB's financial statements in 2012, the credit absorption in the 2009-2012 period ranges between 62.10 percent to 74.89 percent. The low ability of MDBs in turning the capital is also reflected in the placement of excess funds in various financial instruments. Table 3 shows that the IDB place their funds in financial instruments by 44 percent, the IMF reaches more than one capital, and the World Bank even reaches 1.67 of its capital. Placement of funds in various financial instruments also shows that the funds borrowed from the market has not fully able to be distributed in the form of loans, so as to temporarily parked in financial instruments.

Table 3: Loan and Realization Loans Approved at ADB

\begin{tabular}{|c|c|c|c|c|}
\hline Year & $\begin{array}{l}\text { OCR Loan Approvals } \\
\text { (soverign) }\end{array}$ & $\begin{array}{l}\text { OCR Loan } \\
\text { (soverign) }\end{array}$ & Disbursement & Ratio \\
\hline 2009 & $10,568.00$ & $7,449.00$ & & 70.49 \\
\hline 2010 & $8,197.00$ & $5,272.00$ & & 64.32 \\
\hline 2011 & $9,051.00$ & $5,621.00$ & & 62.10 \\
\hline 2012 & $8,295.00$ & $6,221.00$ & & 74.89 \\
\hline
\end{tabular}

Source: financial statement of ADB, 2013, prepared

The above findings are consistent with results reported by CIDA (2013), that ADB programs are relevant to stakeholder needs and national priorities, most ADB programs achieve their development effectiveness objectives and expected results, but findings on sustainability reported in the reviewed IED evaluation reports indicate that sustainability is an area to be improved. The sustainability of results from ADB operations is a concern, with over a half $(53 \%)$ of 38 evaluations reviewed reporting results for this criterion which were "unsatisfactory" or worse. A key problem is the institutional capacity of partners to sustain program benefits with $65 \%$ of 34 evaluations reviewed reporting negative findings. World Bank reported (2011) that in general, The World Bank has been playing a key role in shaping the international aid effectiveness agenda over the years, is a major champion of the Paris Declaration and the AAA, and has mainstreamed the aid effectiveness agenda at the country and corporate levels. But there are some indicators that the target was not reached in 2010, namely aid on budget, strengthen capacity by avoiding parallel, aid is more predictable, program-based approach, joint missions to the field, and joint country analytic work.

The study effectiveness of IMF conducted by Lamdani (2009) found that fewer than 5 percent of the structural conditions called for lasting structural reforms, and only one-third of these were complied with. More than 40 percent of conditions only called for preparing plans or drafting legislation. In view of these figures, it is surprising that only about half of all conditions were met as agreed. Moreover, there was only a weak link between compliance with structural conditionality and subsequent reforms in the corresponding sector-a weak measure of the effectiveness of conditions in bringing about reform. Compliance and effectiveness were higher in the areas of IMF core competency, but even there compliance was only 60 percent. Meanwhile, Ali (2013) founded that countries investigated the challenges facing Islamic finance to promote the growth of SMEs in IDB member countries. SMEs represent one of the import ant drivers of the economic growth and an essential labor intensive sector that might help in reducing the high unemployment in most of IDB member countries. In addition to the effectiveness of the lending problem, the other problems turns out that is not less important is the capital structure. Two things distinguish MBDs with private financial institutions and bilateral donors are in terms of shareholder structure and the status of preferred creditor (Buiter \& Steven, 2002). The African Development Bank, ADB, Inter-American Development Bank and the World Bank are to prioritize lending 
to the government. Therefore, various MDBs may extend financing to the government budget can pay back the loan.

As microfinance institutions, MDBs also have similarities in terms of the risk of legal and institutional arrangements (supporting legal) weak (Buiter \& Steven, 2002). Morduch (1999) and Armendariz de Aghion and Morduch (2000) states that the distinguishing feature of microfinance institutions is the use of social groups to screen and monitor loans, reliance on alternative sources of threat credit to provide incentive payments, and the creation of collateral substitutes such as self-insurance against the failure by the borrower to pay. Study on the effectiveness of MDBs done by Scott (2008). Based on their study, it can be concluded that critical weaknesses in the aid delivery system, such as proliferation and verticalisation, have been identified as reducing the effectiveness of the system taken together and there is little or no consensus on how the system should evolve to address these. Nelson (2013) in his study concluded that the MDBs, include the World Bank and four smaller regional development banks: the African Development Bank (AfDB), the Asian Development Bank (ADB), the European Bank for Reconstruction and Development (EBRD), and the Inter-American Development Bank (IDB), focus on "getting money out the door" (rather than delivering results), are not transparent, and lack a clear division of labor.

In the above context, two things must be prepared by AIIB in the early establishment phase, namely: First, the problem of preferred creditor status and plan of arrangement. However the most fundamental is both in terms of financial viability and nature AIIB financing operations. All financial contracts should be designed through the selection and incentive effects that can be combined with loans on AIIB seniority. The second issue is about the role of the private sector of AIIB. The experience of developing countries and transition economies suggests that the process of adjustment and adaptation in the private sector in the reform does not happen automatically. Although there can be a strong resistance to change in the private sector. Activities of the private sector can demonstrate successful ways to adapt, as well as business practices. There is of course a potentially strong complementarily between public sector and private sector activities of AIIB.

AIIB Rating: One of the key elements in AIIB is capital. AIIB estimated initial capital of U.S. $\$ 50$ billion, which the PRC will account for 50 percent or U.S. \$ 25 billion. Paid-in capital is set at 20 percent and must be paid at the first stage. Thus, at the beginning of the establishment, expected capital raised between US\$ 30 - US\$ 37.5 billion, amounting to 60-75 percent of the initial capital. It is expected to be channeled of AIIB loan of US\$ 5 billion per year and will gradually be increased to US\$ 10 billion. Improving the ability of AIIB in providing loans to member countries, then one additional source of capital that can be explored is through the issuance of debt securities either in the long term (bonds) or short-term (commercial paper). Ease of AIIB in issuing debt securities will be determined by AIIB rating, which indicates the level of risk AIIB. The more risky bonds, the more expensive the costs (interest) are to be paid to investors. This rating is done by independent rating agencies. The information and opinions, independent and credible credit risk from these securities is needed by investors. As an illustration of the various MDBs rating and ability to issue debt securities are as follows:

Table 4: MDBs Rating and Debt to Equity Ratio Outstanding

\begin{tabular}{llll}
\hline MDBs & Rating & Debt to Equity Ratio Outstanding \\
\hline IMF & Bank for International Settlement & Not Rated & 2.75 \\
& Other International Institution & AAA & \\
IDB & Standard \& Poors & AAA & 0.64 \\
& Fitch & AAA & \\
& Moody's & AAA & \\
WB (IBRD) & Other International Institution & AAA & 1.02 \\
ADB & Standard \& Poors & AAA & 0.39 \\
& Fitch & AAA & \\
& Moody's & Aaa & \\
& & & \\
\end{tabular}

Source : financial statements of IDB, IMF, WB.

The above table shows that various of MDBs have very good ratings from various international agencies. With fairly good ratings, then the bonds issued have the lowest risk compared to bonds with a rating below. However, not all MDBs utilizing its ability to issue bonds with low interest. The bond issuance was 
also influenced by the ability of MDBs in loans. If we compare with Table 4, it appears that the low ratio of outstanding debt to equity issuance in line with loan-to-equity ratio. What is AIIB rating? Theoretically its rating will be greatly influenced by the financial policy, capital structure, cash flow protection and financial flexibility (Poulus, 2011). Meanwhile, for AIIB, if the bond issuance will be done in various currencies in countries such as the IMF's founding members, hence the AIIB rating also be affected by government bond rating from each of the founding members. As an illustration government bond rating of several founding members are as follows:

Table 5: Government Bond Ratings Some Founding Members AIIB

\begin{tabular}{lllllllll}
\hline & $\begin{array}{l}\text { S\&P } \\
\text { Rating }\end{array}$ & & $\begin{array}{l}\text { Moody's } \\
\text { Rating }\end{array}$ & & $\begin{array}{l}\text { Fitch } \\
\text { Rating }\end{array}$ & & \multicolumn{2}{c}{ TE } \\
Rating & \\
\hline CAMBODIA & B & STABLE & B2 & STABLE & & & 30.00 & STABLE \\
CHINA & AA- & STABLE & Aa3 & STABLE & A- & STABLE & 78.82 & STABLE \\
INDONESIA & BB+ & STABLE & Baa3 & STABLE & BBB- & STABLE & 48.51 & POSITIVE \\
MALAYSIA & A- & STABLE & A3 & POSITIVE & A- & Negative & 66.50 & STABLE \\
MONGOLIA & BB- & NEGATIVE & B1 & STABLE & B- & NEGATIVE & 36.25 & STABLE \\
PAKISTAN & B- & STABLE & Caa1 & NEGATIVE & & & 10.84 & STABLE \\
PHILIPINES & BBB- & STABLE & Baa3 & POSITIVE & BBB- & STABLE & 45.63 & POSITIVE \\
SINGAPORE & AAA & STABLE & Aaa & STABLE & AAA & STABLE & 98.60 & STABLE \\
SOUTH & A- & STABLE & Aa3 & STABLE & AA- & STABLE & 80.74 & STABLE \\
KOREA & & & & & & & & \\
SRI & B- & STABLE & B1 & STABLE & BB- & STABLE & 37.80 & STABLE \\
LANGKA & & & & & & & & \\
THAILAND & BBB- & STABLE & Baa1 & STABLE & BBB- & Stable & 58.82 & STABLE \\
VIETNAM & BB- & STABLE & B2 & STABLE & B- & Positive & 25.23 & STABLE \\
\hline
\end{tabular}

Source: http://www.tradingeconoics.com/RRT/rating

The table above shows that government bonds rating founding members of AIIB vary between stable, positive and negative. Variations in government bond rating countries AIIB founding members will certainly have an impact on the AIIB rating. In addition, the AIIB ratings at an early phase will also be influenced by the capital structure. Share PRC which reaches 50 percent of the initial capital of AIIB likely to have a positive impact on the rating, given the PRC rating is also pretty good.

Supporting for Proposed AIIB: AIIB formation is one of the PRC government's measures to utilize excess liquidity. As we know that the average outstanding PRC reserves reached 1.5 trillion Yuan (June 2013) the number of foreign exchange reserves of U.S. \$ 3,341,000 million (December 2012) and increased to approximately U.S. \$ 3.66 billion (September 2013). In addition, by forming AIIB, the PRC wants to show the economic power possessed and seeks to increase its role in the decision-making process on global issues. AIIB is also allegedly going to be a vendor-financing scheme for PRC firms, especially the field of construction in order to expand overseas, especially in Southeast Asia. Such efforts will be welcomed by the countries in Southeast Asia that are in need of infrastructure financing sources. Increased infrastructure, either in the form of highways, railways, pipelines and power plants in Southeast Asia will increase the profits of the PRC trade and investment in the region. As we know, Southeast Asia has a population of around 700 million people where most of them are in middle class income levels were relatively stable consumer spending. There is concern that the PRC as the initiator at the same time as the largest shareholder in AIIB will apply tied financing. "Tied" aid financing which would limit the possibility of procurement of more effective and efficient. "Tied" aid financing also potentially occur by means of inserting a consultant/expert, especially Japan (Kimura and Todo, 2010).

PRC wants to play a major role in the MDBs, especially in infrastructure financing. This is motivated, PRC share in a number of MDBs small enough so that the effect is not too large. Meanwhile, the desire to increase the share of PRC in various MDBs did not get a response from countries majority shareholder. The initiative is suppose to be a step formation of AIIB, PRC to reduce the dominance of Japan in the region, either through ADB, ASEAN +3 Process, Process ASEAN and other bilateral relations. PRC and Japan, each will attempt to gain support for their respective interests are associated with the formation AIIB PRC and Japan related to the sustainability of ADB. On the other hand, South Korea will tend to follow the flow of the greatest support that will be given to either party. Meanwhile, from the standpoint of the interests of ASEAN, ASEAN is currently pursuing an ambitious target to realize the ASEAN 
Economic Community in 2015. To support these objectives, it's required substantial investment in the infrastructure sector. According to research by the ADB, ASEAN requires an investment of about US\$ 8 trillion to the national infrastructure development and US\$290 trillion for infrastructure development in the region in 2010 to 2020 . ASEAN is also working to realize the connectivity among its members; in this case one of them is physical connectivity (infrastructure).

On the other hand, sources of financing are available either by individually or supported from multilateral sources is very limited. Moreover, efforts to involve the private sector through Public Private partnership (PPP) mechanisms also cannot run well. As an alternative measure, with the support of ADB, ASEAN formed the ASEAN Infrastructure Fund with the aim of accelerating the development of infrastructure to promote economic integration of ASEAN. However, AIF also has limited capital amounting to US\$ 485.2 million derived from the contribution of ASEAN countries and ADB. Based on this fact, the existence of AIIB will be expected to be an alternative source of financing for infrastructure development in ASEAN countries. Furthermore AIIB will be expected to synergize with the AIF in accelerating infrastructure development to encourage ASEAN economic integration through the provision of financing, project preparation and project evaluation. Based on this reality, the existence of AIIB will be expected to be an alternative source of financing for infrastructure development in ASEAN countries. Furthermore AIIB will be expected to synergize with the AIF in accelerating infrastructure development to encourage ASEAN economic integration through the provision of financing, project preparation and project evaluation.

\section{Conclusion and Recommendations}

AIIB initiative is the establishment of a relevant step with the spirit of accelerating economic development and integration of Asia through the promotion of investment in the infrastructure sector. AIIB priority areas which include transportation, energy, communication, industry, and agriculture are also becoming priority in developing countries. Openness in terms of membership (open regionalism) is also showed that AIIB is not be managed exclusively by the emerging countries in Asia but also open to countries outside the region. In terms of capital, the amount of initial capital is estimated at US\$50 billion, is also a good step though when compared to the needs of infrastructure financing in Asia. However, even with these limitations, AIIB will be able to collaborate and synergize with existing MDBs and the current AIF. To that end, AIIB must come up with on unique and innovative products compared to the facilities provided by the MDBs at this time. Different products with existing products will also be more likely to be used by countries that need considering in some countries, notably Indonesia has declared policy of limiting foreign debt. One of the key elements in AIIB is capital. AIIB estimated initial capital of U.S. \$ 50 billion, which the PRC will account for 50 percent or U.S. \$ 25 billion. Improving the ability of AIIB in providing loans to member countries, then one additional source of capital that can be explored is through the issuance of debt securities either in the long term or short-term. Ease of AIIB in issuing debt securities will be determined by AIIB rating, which indicates the level of risk AIIB. Meanwhile, for AIIB, if the bond issuance will be done in various currencies in countries, hence the AIIB rating also is affected by government bond rating from each of the founding members.

Countries in the region can support the existence of AIIB with consideration of the financing gap for infrastructure financing where high financing needs cannot be met by the MDBs, so AIIB can be as an alternative source of financing. On the other hand, the countries in the region may also be refused for joining with AIIB with consideration of (i) AIIB likely to be dominated by the PRC, given the state a majority stake held by the PRC and (ii) the possibility of higher interest rates to be charged of AIIB as stated in the issue paper prepared by the PRC, which is a long-term loan with an interest rate that is equivalent to that applied by other development banks like ADB and IBRD loans OCR loans. Based on the results of the study, in general, the main objective of the initiative can be understood by AIIB establishment, so that the countries in the region can support it. However, in terms of the details are still many things that are need to be completed by the PRC, including the main AIIB relationship with MDBs like ADB and IDB and AIIB association with AIF. In this case, AIIB should be complementary to the facilities provided by the MDBs at this time. To that end, AIIB must come up with unique and innovative products, for example by forming a special unit that can collaborate with the government in PPP scheme. This mechanism actually is not a new thing because the Word Bank has already done through the International Finance Cooperation (IFC).

In addition, the PRC also need to complete a proposal for the establishment of AIIB in matters of a technical nature such as the allocation of capital distribution for the founding members, payment of 
capital (once or in several stages). If all the capital is paid in cash or may in the form of a promissory note, as well as the governance of the institution. AIIB also need to customize the capital raising plan ahead, whether through the issuance of bonds, hybrid capital, or other innovative measures. The PRC are expected to be transparent in every process at both stages in the establishment and operation of AIIB. It should be clear what advantages as founding members, towards funding of AIIB and ensure it will not happen as tied financing. This condition will be considered by countries in the Asian region to join as founding members of AIIB. AIIB is ability in channeling loans to member countries will be severely limited if only relying on the capital deposited member states. For that reason, AIIB will seek other sources of funding such as the issuance of debt securities both long and short term. AIIB ability to obtain funds from the market will be influenced by the rating. The better of AIIB rating will more easily get cheap funding sources. Therefore, if the debt issuance will use multiple currencies, AIIB should consider the government bonds rating of its member countries. Considering the variation of the government bonds rating of its member countries, debt issuance should be focused on member's countries that have good government bond rating, so the AIIB rating will be good.

\section{References}

Anat, A. \& Martin, H. (2014). Banks are not a special case on debt-equity ratio, http://www.ft.com/intl/cms/s/0/25e34b6c-befb-11e2-87ff-00144feab7de.html.

Ali, A. E. E. S. (2013). The Challenges of Islamic Trade Finance in Promoting SMEs in IDB Member Countries, Islamic Research and Training Institute, IRT Working Paper 1434-06 Desember.

Armendáriz de Aghion, B. \& Morduch, J. (2000). Microfinance Beyond Group Lending. Economics of Transition, 8(2), 401-420.

Aschauer, D. A. (1989). Is Publik Expenditure Productive? Journal of Monetary Economics, 2, 177-200.

Berndt, E. R. \& Hansson, B. (1991). Measuring the Contribution of Publik Infrastructure Capital in Sweden, National Bureau of Economic Research Working Paper Number 3842.

Buiter, W. \& Steven, F. (2002). What should the multilateral development banks do? European Bank for Reconstruction and Development, Working Paper No. 74.

Calderon, C. \& Serven, L. (2002). The Output Cost of Latin America's Infrastructure Gap, Central Bank of Chile Working Papers Number 186.

Canadian International Development Agency (CIDA). (2013). Development Effectiveness Review of the Asian Development Bank 2006-2010, final report.

Canning, D. (1999). The Contribution of Infrastructure to Aggregate Output, World Bank Working Paper Number 2246.

Kimura, H. \& Todo, Y. (2010). Is Foreign Aid a Vanguard of Foreign Direct Investment? A Gravity-Equation Approach. World Development, 38(4), 482-497.

Lamdani, R. (2009). Assessing the Effectiveness of IMF Structural Conditionality. The Journal of Social Science, 3, 133-148

Marianne, F. (1999). Financing The Future: Infrastructure Needs in Latin America, 2000-05, World Bank Working Paper Number 2545.

Morduch, J. (1999). The Microfinance Promise. Journal of Economic Literature, 37(4), 1569-1614.

Morrison, C. J. \& Schwartz, A. E. (1992). State Infrastructure and Productive Performance, National Bureau of Economic Research Working Paper Number 3981.

Nelson, R. M. (2013). Multilateral Development Banks: Overview and Issues for Congress, Congressional Research Service, November.

Norton, S. W. (1992). Transaction Costs, Telecommunications, and the Microeconomics of Macroeconomic Growth. Economic Development and Cultural Change, 40, 175-196.

OECD. (2010). Infrastructure to 2030: Mapping Policy For Electricity, Water And Transport, Volume 2.

OECD. (2010). Global Infrastructure Needs and Financing into the Future, OECD Secretary-General's Advisory Unit and International Futures Program RUSI, London, October.

Poulus, S. (2011). Peringkat Obligasi, bahan pelatihan manajemen obligasi daerah tahap middle bagi staff BPKD Pemprof DKI Jakarta, 23-27 Mei.

Röller, L. H. \& Waverman, L. (1996). The Impact of Telecommunications Infrastructure on Economic Growth and Development: A first Look at the Data, in The Implications of Knowledge-Based Growth for Micro-Economic Policies, The University of Calgory Press.

Scott, L. (2008). Assessing Multilateral Organization Effectiveness, Ministry of Foreign Affairs of Denmark, evaluation Study, March 2008/3. 
United Nation-ESCAP. (2006). Enhancing Regional Cooperation Including That Related To Disaster Management, United Nations publication Sales No. E.06.II.F.13 New York.

World Bank. (1994). World Development Report 1994: Infrastructure for Development, New York: Oxford University Press.

The World Bank. (2011). The World Bank Aid and Effectiveness: Performance to Date and Agenda Ahead, November. 